\title{
The association of adenoma size with the biochemical parameters and cardio-metabolic risk factors in primary hyperparathyroidism
}

\section{Primer hiperparatiroidide adenom hacmi ile labaratuvar parametreleri ve kardiyo-metabolik risk faktörlerinin ilişkisi}

Muhammed Kizilgul, Mustafa Caliskan, Bekir Ucan, Erkam Sencar, Davut Sakiz, Erman Cakal, Mustafa Ozbek

Department of Endocrinology and Metabolism, University of Health Sciences, Diskapi Training and Research Hospital, Ankara, Turkey

Geliş Tarihi: 17.10.2017 Kabul Tarihi: 05.12.2017～Doi: 10.21601/ortadogutipdergisi.344895

\begin{abstract}
Aim: The studies conducted to investigate the association between biochemical manifestations of hyperparathyroidism such as serum parathyroid hormone, serum calcium, and serum phosphate levels, and parathyroid adenoma weight and volume have conflicting results. We aimed to investigate whether there is an association of preoperative size of adenoma with laboratory parameters and cardio-metabolic risk factors in patients with primary hyperparathyroidism.

Material and Method: Seventy-five patients with PHPT and 96 control subjects were enrolled in the study. Demographic, anthropometric and biochemistry data were recorded. Correlation analysis was used for determining the relation between adenoma volume and cardio-metabolic parameters. Preoperative adenoma volume was calculated by the ellipsoid model formula.
\end{abstract}

Results: Mean age was similar between groups (52.69 \pm 10.91 to $53.33 \pm 7.70, \mathrm{p}: 0.667)$. Mean size of adenoma was $1.42 \pm 2.62 \mathrm{~cm} 3$. Size of adenoma was positively correlated with calcium and parathormone levels and negatively correlated with vitamin D level $(\mathrm{p}<0.05)$. Size of adenoma was not correlated with cardio-metabolic risk factors including systolic blood pressure, diastolic blood pressure, age, fasting plasma glucose, lipid profile, body mass index, carotis intima media thickness, CRP and HOMA-IR ( $>0.05)$. PTH, calcium, phosphorus or vitamin D levels were also not correlated cardio-metabolic risk factors.

Conclusions: Adenoma volume has a correlation with parathormone, calcium, phosphorus and vitamin D levels, however, it is not associated with cardio-metabolic risk factors.

Keywords: Primary hyperparathyroidism, adenoma volume, cardio-metabolic risk factors 


\section{Öz}

Amaç: Primer hiperparatiroidili hastalarda, paratiroid adenom ağırlığı veya hacminin hiperparatiroidinin biyokimyasal parametreleri ile ilişkisini araştıran çalışmaların sonuçları çelişkilidir. Bu çalışmada, primer hiperparatiroidili hastalarda preoperatif adenom hacmi ile labaratuvar parametreleri ve kardiyo-metabolik risk faktörleri arasındaki ilişkinin değerlendirilmesini amaçladık.

Gereç ve Yöntem: Çalışmaya primer hiperparatiroidisi olan 75 hasta ve 96 kontrol olgusu alındı. Demografik, antropometrik ve biyokimyasal veriler kaydedildi. Adenom hacmi ile labaratuvar ve kardiyo-metabolik risk faktörleri arasındaki ilişki korrelasyon analizi ile değerlendirildi. Preoperatif adenoma hacmi ellipsoid model formülü ile hesaplandı.

Sonuçlar: Ortalama yaş her iki grupta benzerdi ( $52.69 \pm 10.91$ to $53.33 \pm 7.70, \mathrm{p}=0.667)$. Ortalama adenom hacmi $1.42 \pm 2.62 \mathrm{~cm} 3$ idi. Paratiroid adenom hacmi, parathormon ve kalsiyum düzeyleri ile pozitif korrele iken, vitamin D düzeyleri ile negatif korrele idi $(\mathrm{p}<0.05)$. Paratiroid adenom hacmi, kardiyo-metabolik risk faktörleri olan sistolik ve diyastolik kan basınc1, yaş, açlık plazma glukozu, lipid profili, vücut kitle indeksi, karotis intima media kalınlığı, CRP ve HOMA-IR ile ilişkili değildi ( $\mathrm{p}>0.05$ ). Parathormon, kalsiyum, fosfor veya vitamin D düzeyleri ile kardiyometabolik risk faktörleri arasında ilişki saptanmadı $(\mathrm{p}>0.05)$.

Sonuç: Paratiroid adenoma hacmi ile parathormon, kalsiyum ve vitamin D düzeyleri arasında korrelasyon olmasına rağmen paratiroid adenoma hacmi ile kardiyo-metabolik risk faktörleri arasında ilişki saptanmadı.

Anahtar Kelimeler: Primer hiperparatiroidi, adenoma hacmi, kardiyo-metabolik risk faktörleri

\section{Introduction}

Elevated serum calcium and elevated or non-suppressed levels of parathyroid hormone (PTH) characterize primary hyperparathyroidism (PHPT) [1]. A single benign parathyroid adenoma is the most common lesion found in PHPT patients. There is a substantial increase in the incidence of PHPT in countries where biochemical screening tests become available [2]. Cardiomyocytes, endothelial cells, and smooth muscle cells express PTH receptors [3], and experimental and clinical studies have shown that increased PTH was associated with myocardial fibrosis, calcification, and hypertrophy [4]. Increased levels of PTH have been demonstrated in hypertension [5], left ventricular hypertrophy [6], atrial fibrillation [7] and could predict cardiovascular mortality [8], which may suggest the hypothesis that increased PTH is associated with cardiovascular disease risk. On the other hand, some studies did not support this hypothesis $[9,10]$. Even mild primary hyperparathyroid patients have increased cardiovascular abnormalities and dysfunction and mortality many of which improved with parathyroidectomy [11-15]. Preoperative biochemical markers of calcium homeostasis and ultrasonographic features of parathyroid adenoma may affect the surgical decisions related to the extent of neck exploration and parathyroid gland excision. The studies conducted to investigate the association between biochemical manifestations of hyperparathyroidism such as serum parathyroid hormone, serum calcium, and serum phosphate levels, and parathyroid adenoma weight and volume have conflicting results [16-21].
We aimed to investigate whether there is an association of preoperative size of adenoma with laboratory parameters and cardio-metabolic risk factors in patients with primary hyperparathyroidism.

\section{Material and Method}

\section{Patient selection}

Seventy-five patients with PHPT diagnosed in Diskapi Training and Research Hospital between 2012 and 2017 and 96 control subjects were enrolled in the study. Ethics committee approval and written informed consent of participants were obtained before the study. Patients with multiple endocrine neoplasia, parathyroid cancer, thyroid cancer, hyperparathyroidism-jaw tumor syndrome and patients had known to interfere with calcium and vitamin D metabolism for at least 2 weeks before hospital admission were excluded. Patients diagnosed with familial hypocalciuric hypercalcemia were also excluded. None of our patients used any medicine that have effect on calcium metabolism. PHPT was diagnosed by demonstrating persistent hypercalcemia in the presence of inappropriately normal or elevated PTH concentrations [22]. All patients underwent parathyroidectomy. Seventy patients had pathologically confirmed single parathyroid adenoma, 1 patient had parathyroid carcinoma, 2 patients had parathyroid hyperplasia, 2 patients had double parathyroid adenoma.

\section{Clinical, biochemical and hormonal measurements}

Baseline demographic data, clinical characteristics, blood sampling were obtained in all study subjects. Weight, height, circumferences of waist (WC) and hip (HC), body 
mass index (BMI), systolic and diastolic blood pressure (BP) were measured. BMI was calculated as weight $(\mathrm{kg}) /$ height $(\mathrm{m}) 2$. All patients underwent a biochemical, and hormonal examination including serum glucose, albumin, total calcium, 24-hour urinary calcium, phosphorus, creatinine, hs-CRP, total cholesterol, triglyceride, lowdensity lipoprotein cholesterol (LDL-C) and high-density lipoprotein cholesterol (HDL-C) levels the morning after an overnight fast, by using colorimetric methods. The concentration of plasma parathyroid hormone (PTH) was measured using an intact PTH assay (chemiluminescent immunoassay with an Immulite 2000; normal range 12$65 \mathrm{pg} / \mathrm{ml}$ ). Plasma 25-OH vitamin D was measured via radioimmune assay. Insulin resistance was calculated by the homeostasis model assessment (HOMA-IR) [23].

Parathyroid ultrasonography (US) was performed using High-resolution B-mode ultrasound images (EUB 7000 HV; Hitachi, Tokyo, Japan) with a 13-MHz linear array transducer. The volume of parathyroid adenoma was calculated by the ellipsoid model formula (length $\mathrm{x}$ thickness $\mathrm{x}$ width $\mathrm{x}$ 0.52) [24].

Carotid intima-media thickness (CIMT) was measured for assessing carotid atherosclerosis. CIMT was defined as the distance between the blood-intima and media-adventitia boundaries on B-mode imaging high-resolution ultrasound system (EUB 7000 HV; Hitachi, Tokyo, Japan).

Blood pressure was measured from both arms using mercury sphygmomanometer based on Korotkoff phase I and phase $\mathrm{V}$ sounds with the subject rested in a sitting position for a minimum of 10 minutes. A second measurement was taken from the arm that had a higher value. The mean systolic and diastolic blood pressure values were calculated from the two measurements, which were taken at least three minutes apart.

Statistical analysis: Statistical analysis was performed using JMP 13.0.1 software (SAS Institute, Cary, NC, USA). Descriptive analyses were expressed as mean \pm standard deviation (SD) and percentages (\%). KolmogorovSmirnov or Shapiro-Wilk W was used for normality. Chi-square test or Fisher's exact test, where appropriate, was used for categorical variables. The Student's t-test for normally distributed continuous variables and MannWhitney $U$ test for continuous variables, which were not normally distributed were used. Correlations were analyzed using Pearson and Spearman's correlation. $\mathrm{P}<0.05$ was considered as statistically significant.

\section{Results}

Seventy-five patients with PHPT and 96 controls were included in the study. Mean age was similar between groups ( $52.69 \pm 10.91$ to $53.33 \pm 7.70, \mathrm{p}: 0.667)$. Mean size of adenoma was $1.42 \pm 2.62 \mathrm{~cm} 3$. Sex distribution, BMI was similar between groups ( $>00.05)$. Vitamin $\mathrm{D}$, fasting plasma glucose, creatinine, HDL-C, LDL-C, triglyceride and CRP levels were similar between groups ( $\mathrm{p}>0.05)$. Systolic blood pressure, diastolic blood pressure, calcium and parathormone levels were significantly higher in PHPT group $(\mathrm{p}<0.0001)$. Phosphorous was significantly lower in PHPT group $(\mathrm{p}<0.0001)$. CIMT and HOMA-IR were significantly higher in PHPT group $(\mathrm{p}<0.05)$ (Table 1$)$.

Table 1. Clinical and demographic characteristics of patients and controls

\begin{tabular}{|l|c|c|c|c|c|}
\hline & \multicolumn{2}{|c|}{ PHPT Group (n:75) } & \multicolumn{2}{c|}{ Control Group (n:96) } & \multirow{2}{*}{ p } \\
\cline { 1 - 4 } & Mean or n & SD or \% & Mean or n & SD or \% & \\
\cline { 1 - 4 } Age (years) & 52.69 & 10.91 & 53.33 & 7.70 & 0.667 \\
\hline Sex (Female) & 65 & 87 & 73 & 76 & 0.081 \\
\hline BMI (kg/m2) & 30.61 & 5.12 & 29.55 & 4.34 & 0.159 \\
\hline Systolic blood pressure (mmHg) & 136.56 & 15.10 & 121.72 & 10.57 & $<0.0001$ \\
\hline Diastolic blood pressure (mmHg) & 83.81 & 7.46 & 78.76 & 5.56 & $<0.0001$ \\
\hline Calcium (mg/dL) & 11.11 & 0.81 & 9.37 & 0.38 & $<0.0001$ \\
\hline Phosphorous (mg/dL) & 2.68 & 0.43 & 3.44 & 0.50 & $<0.0001$ \\
\hline Parathormone (pg/mL) & 236.89 & 223.96 & 60.55 & 25.40 & $<0.0001$ \\
\hline Vitamin D (ng/mL) & 14.76 & 12.71 & 15.31 & 11.76 & 0.776 \\
\hline Fasting Plasma Glucose (mg/dL) & 90.59 & 8.79 & 88.27 & 8.11 & 0.079 \\
\hline Creatinine (mg/dL) & 0.76 & 0.20 & 0.90 & 1.00 & 0.191 \\
\hline LDL-Cholesterol (mg/dL) & 123.93 & 32.18 & 119.25 & 24.04 & 0.299 \\
\hline HDL-Cholesterol (mg/dL) & 51.54 & 11.99 & 51.95 & 11.66 & 0.825 \\
\hline Triglyceride (mg/dL) & 147.19 & 61.83 & 142.43 & 69.79 & 0.641 \\
\hline CIMT (cm) & 0.67 & 0.13 & 0.60 & 0.10 & 0.0009 \\
\hline CRP(mg/L) & 3.41 & 3.31 & 3.34 & 2.98 & 0.882 \\
\hline HOMA-IR & 2.93 & 1.87 & 2.20 & 1.35 & 0.005 \\
\hline
\end{tabular}


Size of adenoma was positively correlated with calcium and parathormone levels and negatively correlated with phosphorous level $(p<0.05)$. Size of adenoma was not correlated with systolic blood pressure, diastolic blood pressure, age, fasting plasma glucose, creatinine, LDL-C, HDL-C, triglyceride, BMI, CIMT, CRP and HOMA-IR $(\mathrm{p}>0.05)$ in PHPT group (Table 2).

Table 2. Correlation of the adenoma size with the clinical and laboratory parameters in PHPT group

\begin{tabular}{|l|c|c|}
\hline & $\begin{array}{c}\text { Correlation } \\
\text { Coefficient }\end{array}$ & $\mathrm{p}$ \\
\hline Systolic blood pressure (mmHg) & 0.110 & 0.377 \\
\hline Diastolic blood pressure (mmHg) & 0.046 & 0.710 \\
\hline 24-hour urinary calcium (mg/day) & 0.057 & 0.661 \\
\hline Age (years) & 0.034 & 0.781 \\
\hline Calcium (mg/dL) & 0.307 & 0.011 \\
\hline Phosphorous (mg/dL) & -0.170 & 0.166 \\
\hline Parathormone (pg/mL) & 0.522 & $<0.0001$ \\
\hline Vitamin D (ng/mL) & -0.457 & $<0.0001$ \\
\hline Fasting Plasma Glucose (mg/dL) & -0.226 & 0.064 \\
\hline Creatinine (mg/dL) & 0.037 & 0.762 \\
\hline LDL-cholesterol (mg/dL) & -0.200 & 0.102 \\
\hline Triglyceride (mg/dL) & 0.018 & 0.884 \\
\hline HDL-cholesterol (mg/dL) & 0.105 & 0.395 \\
\hline BMI (kg/m2) & 0.068 & 0.584 \\
\hline CIMT (cm) & 0.025 & 0.839 \\
\hline CRP (mg/L) & 0.017 & 0.893 \\
\hline HOMA-IR & -0.125 & 0.314 \\
\hline
\end{tabular}

Parathyroid hormone levels were positively correlated with calcium levels, and negatively correlated with phosphorous and vitamin D levels $(\mathrm{p}<0.05)$. Parathyroid hormone levels were not correlated with systolic blood pressure, diastolic blood pressure, age, fasting plasma glucose, creatinine, LDL-C, HDL-C, triglyceride, BMI, CIMT, CRP and HOMA-IR in PHPT group ( $>0.05$ ) (Table 3 ).

Table 3. Correlation of the parathormone levels with the clinical and laboratory parameters in PHPT group

\begin{tabular}{|l|c|c|}
\hline & $\begin{array}{c}\text { Correlation } \\
\text { Coefficient }\end{array}$ & $\mathbf{p}$ \\
\hline Systolic blood pressure (mmHg) & -0.042 & 0.724 \\
\hline Diastolic blood pressure (mmHg) & -0.107 & 0.371 \\
\hline 24-hour urinary calcium (mg/day) & 0.107 & 0.385 \\
\hline Age (years) & -0.041 & 0.728 \\
\hline Calcium (mg/dL) & 0.341 & 0.0028 \\
\hline Phosphorous (mg/dL) & -0.242 & 0.037 \\
\hline Vitamin D (ng/mL) & -0.621 & $<0.0001$ \\
\hline Fasting Plasma Glucose (mg/dL) & 0.071 & 0.546 \\
\hline Creatinine (mg/dL) & -0.224 & 0.053 \\
\hline LDL-cholesterol (mg/dL) & -0.386 & 0.0007 \\
\hline Triglyceride (mg/dL) & -0.169 & 0.151 \\
\hline HDL-cholesterol (mg/dL) & 0.013 & 0.912 \\
\hline BMI (kg/m2) & 0.059 & 0.618 \\
\hline CIMT (cm) & 0.011 & 0.924 \\
\hline CRP (mg/L) & -0.080 & 0.500 \\
\hline HOMA-IR & -0.005 & 0.969 \\
\hline
\end{tabular}

Calcium, phosphorus or vitamin D levels were not correlated with systolic blood pressure, diastolic blood pressure, age, fasting plasma glucose, creatinine, LDL-C, HDL-C, triglyceride, BMI, CIMT, CRP and HOMA-IR in PHPT group ( $\mathrm{p}>0.05)$ (Table 4).

Table 4. Correlation of the calcium, phosphorus and vitamin D levels with the clinical and laboratory parameters in PHPT group

\begin{tabular}{|l|c|c|c|c|c|c|}
\hline & \multicolumn{2}{|c|}{ Calcium } & \multicolumn{2}{c|}{ Phosphorus } & \multicolumn{2}{c|}{ Vitamin D } \\
\hline & CC & p & CC & p & CC & p \\
\hline Systolic blood pressure (mmHg) & 0.096 & 0.423 & -0.063 & 0.599 & 0.006 & 0.962 \\
\hline Diastolic blood pressure (mmHg) & 0.031 & 0.793 & 0.004 & 0.975 & -0.148 & 0.216 \\
\hline 24-hour urinary calcium (mg/day) & 0.152 & 0.215 & -0.165 & 0.178 & 0.117 & 0.341 \\
\hline Age (years) & 0.028 & 0.813 & 0.044 & 0.710 & -0.070 & 0.553 \\
\hline Fasting Plasma Glucose (mg/dL) & -0.197 & 0.091 & -0.117 & 0.316 & -0.128 & 0.273 \\
\hline Creatinine (mg/dL) & 0.224 & 0.054 & 0.111 & 0.342 & 0.101 & 0.390 \\
\hline LDL-cholesterol (mg/dL) & -0.225 & 0.054 & 0.137 & 0.245 & 0.108 & 0.358 \\
\hline Triglyceride (mg/dL) & 0.004 & 0.976 & 0.151 & 0.198 & 0.085 & 0.474 \\
\hline HDL-cholesterol (mg/dL) & 0.236 & 0.043 & 0.170 & 0.148 & -0.134 & 0.254 \\
\hline BMI (kg/m2) & 0.041 & 0.732 & 0.088 & 0.455 & -0.110 & 0.350 \\
\hline CIMT (cm) & 0.170 & 0.144 & 0.014 & 0.907 & 0.006 & 0.960 \\
\hline CRP (mg/L) & -0.064 & 0.591 & 0.206 & 0.080 & 0.065 & 0.588 \\
\hline HOMA-IR & -0.028 & 0.814 & 0.073 & 0.538 & 0.119 & 0.311 \\
\hline CC: Cortan
\end{tabular}

CC: Correlation coefficient 


\section{Discussion}

In our study, the preoperative adenoma volume was positively correlated with calcium and parathormone levels and negatively correlated with vitamin D levels, however, it did not have an association with cardio-metabolic risk factors including blood pressure, age, BMI, lipid profile, CRP, HOMA-IR, CIMT.

Several studies evaluated the relation between adenoma size and laboratory findings in PHPT. Rutledge et al reported an association between PTH and calcium levels with adenoma volume [18]. Williams et al found a considerable correlation between adenoma weight and serum PTH level, however, this correlation was lost after excluding of two extraordinarily heavy adenomas from the analysis [25]. Bindlish et al found a positive correlation between PTH and adenoma weight and a negative correlation between adenoma weight and phosphate [17]. In a retrospective study, Mozes et al demonstrated a positive correlation between PTH and gland weight [26]. A study showed that the adenoma weight was significantly associated with the risk of death after treatment of PHPT [21]. Kamani et al found a substantial correlation between serum PTH and calcium levels regarding parathyroid adenoma volume and weight [27]. On the other hand, some authors have failed to support a relationship between biochemical parameters of hyperparathyroidism with adenoma size $[16,19]$. In our study, the preoperative adenoma volume was positively correlated with calcium and parathormone levels and negatively correlated with vitamin D levels.

Several studies suggested a positive correlation between PTH and cardiovascular risk. A recent study demonstrated an independent association between PTH and nocturnal systolic blood pressure, mean 24-hour pulse wave velocity, and left ventricular mass index. PTH may induce vascular and cardiac remodeling in primary hyperparathyroidism [28]. However, some studies did not support this hypothesis $[9,10]$. Although there was a correlation between adenoma size and PTH, we did not observe an association between parathormone levels and cardio-metabolic risk factors in our study.

Hypertension, hyperlipidemia, CIMT, CRP, and insulin resistance are all associated with increased risk for cardiovascular disease [29,30]. Patients with PHPT have increased the risk for cardiovascular disease and these patients have increased mortality, substantially due to cardiovascular death [31]. Several risk factors for cardiovascular disease (CVD) are observed in PHPT patients, including hypertension and, elevated CIMT, insulin resistance and CRP [32-35]. In our study, SBP, DBP, HOMA-IR, and CIMT were higher in PHPT group, however, CRP, lipid profile and fasting plasma glucose were similar. None of the cardio-metabolic risk factors were associated with adenoma volume.

Adenoma weight is correlated with the degree of vitamin D deficiency in PHPT [36]. However, Moosgaard B et al demonstrated that low vitamin $\mathrm{D}$ levels were associated with an aggravated clinical presentation of PHPT but did not have an effect on adenoma size [37]. In our study, preoperative adenoma volume is negatively correlated with vitamin D levels.

During last decades, the clinical presentation of PHPT has changed from classic symptomatic disease in which renal and/or skeletal manifestations are observed to asymptomatic disease. Most of the patients are diagnosed in very early stage of the disease. Many studies support the association of PTH and hyperparathyroidism with cardiovascular disease risk. We found a positive correlation between PTH and parathyroid adenoma volume however, neither PTH nor adenoma volume were associated with cardio-metabolic risk factors. These findings might be explained by most of our patients could be in the early stage of the disease that are not able to represent an association with cardio-metabolic risk factors.

Being a single center study and small sample size are main limitations of our study.

In conclusion, adenoma size is correlated with parathormone, calcium, phosphorus and vitamin D levels in patients with primary hyperparathyroidism, however, it is not correlated with cardio-metabolic risk factors which have been demonstrated to increase in these patients

\section{Declaration of conflicting interests}

The author declared no conflicts of interest with respect to the authorship and/or publication of this article. 


\section{References}

1. Minisola S, Pepe J, Piemonte S C, Cipriani C. The diagnosis and management of hypercalcaemia. BMJ 2015;350: h2723.

2. Bilezikian JP, Cusano NE, Khan AA, Liu J-M, Marcocci C, Bandeira F. Primary hyperparathyroidism. Nat Rev Dis Prim 2016; 2:16033.

3. Schluter KD, Piper HM. Cardiovascular actions of parathyroid hormone and parathyroid hormone-related peptide. Cardiovasc Res 1998; 37: 34-41.

4. Fitzpatrick LA, Bilezikian JP, Silverberg SJ. Parathyroid hormone and the cardiovascular system. Curr Osteoporos Rep 2008; 6: 77-83.

5. Taylor EN, Curhan GC, Forman JP. Parathyroid hormone and the risk of incident hypertension. J Hypertens 2008; 26: 1390-4.

6. Saleh FN, Schirmer H, Sundsfjord J, Jorde R. Parathyroid hormone and left ventricular hypertrophy. Eur Heart J 2003; 24: 2054-60.

7. Rienstra M, Lubitz SA, Zhang ML, Cooper RR, Ellinor PT. Elevation of parathyroid hormone levels in atrial fibrillation. J Am Coll Cardiol 2011; 57:2542-3.

8. Hagström E, Hellman P, Larsson TE, et al. Plasma parathyroid hormone and the risk of cardiovascular mortality in the community. Circulation 2009; 119:2765-71.

9. Welsh P, Doolin O, McConnachie A, et al. Circulating 25OHD, dietary vitamin D, PTH, and calcium associations with incident cardiovascular disease and mortality: The MIDSPAN family study. J Clin Endocrinol Metab 2012; 97:4578-87.

10. Folsom AR, Alonso A, Misialek JR, et al. Parathyroid hormone concentration and risk of cardiovascular diseases: The Atherosclerosis Risk in Communities (ARIC) study. Am Heart J 2014; 168: 296-302.

11. Smith JC, Page MD, John R, et al. Augmentation of central arterial pressure in mild primary hyperparathyroidism. J Clin Endocrinol Metab 2000; 85: 3515-9.

12. Yu N, Donnan PT, Flynn RW V, et al. Increased mortality and morbidity in mild primary hyperparathyroid patients. the Parathyroid Epidemiology and Audit Research Study (PEARS). Clin Endocrinol (Oxf) 2010;73:30-4.

13. Nilsson IL, Åberg J, Rastad J, et al. Circadian cardiac autonomic nerve dysfunction in primary hyperparathyroidism improves after parathyroidectomy. Surgery 2003; 134: 1013-9

14. Piovesan A, Molineri N, Casasso F et al. Left ventricular hypertrophy in primary hyperparathyroidism. Effects of successful parathyroidectomy. Clin Endocrinol (Oxf) 1999; 50: 321-8.
15. Stefenelli $\mathrm{T}$, Abela $\mathrm{C}$, Frank $\mathrm{H}$ et al. Cardiac abnormalities in patients with primary hyperparathyroidism: implications for follow-up. J Clin Endocrinol Metab 1997; 82: 106-12.

16. Randhawa PS, Mace AD, Nouraei SAR, Stearns MP. Primary hyperparathyroidism: Do perioperative biochemical variables correlate with parathyroid adenoma weight or volume? Clin Otolaryngol 2007; 32: 179-84.

17. Bindlish V, Freeman JL, Witterick IJ, Asa SL. Correlation of biochemical parameters with single parathyroid adenoma weight and volume. Head Neck 2002; 24: 1000-3.

18. Rutledge R, Stiegel M, Thomas Jr. CG, Wild RE. The relation of serum calcium and immunoparathormone levels to parathyroid size and weight in primary hyperparathyroidism. Surgery 1985; 98: 1107-12.

19. Dubost C, Bordier PJ, Ferry J GJ. The estimation of parathormone in primary hyperparathyroidism. Nouv Press Med 1978; 7: 21-5.

20. Wagner PK, Rothmund M. Correlation of tumor weight and typical pathologic laboratory parameters in primary and secondary hyperparathyroidism. Langenbecks Arch Chir 1983; 360: 133-9

21. Hedbäck G, Odén A, Tisell LE, Hedback G, Oden A. Parathyroid adenoma weight and the risk of death after treatment for primary hyperparathyroidism. Surgery 1995; 117: 134-9.

22. Bilezikian JP, Potts JT, El-Hajj Fuleihan G et al. Summary statement from a workshop on asymptomatic primary hyperparathyroidism: A perspective for the 21st century. J Clin Endocrinol Metab. 2002; 87: 5353-61

23. Mather KJ, HuntAE, Steinberg HO et al. Repeatability characteristics of simple indices of insulin resistance: Implications for research applications. J Clin Endocrinol Metab 2001; 86: 5457-64.

24. Vitti P, Rago T, Mazzeo S et al. Thyroid blood flow evaluation by color-flow doppler sonography distinguishes Graves' disease from Hashimoto's thyroiditis. J Endocrinol Invest 1995; 18: 857-61

25. Williams JG, Wheeler MH, Aston JP, Brown RC, Woodhead JS. The relationship between adenoma weight and intact (1-84) parathyroid hormone level in primary hyperparathyroidism. Am J Surg 1992; 163: 301-4.

26. Mózes G, Curlee KJ, Rowland CM et al. The predictive value of laboratory findings in patients with primary hyperparathyroidism. J Am Coll Surg 2002; 194: 126-30.

27. Kamani F, Najafi A, Mohammadi SS, Tavassoli S, Shojaei SP. Correlation of Biochemical Markers of Primary Hyperparathyroidism with Single Adenoma Weight and Volume. Indian J Surg 2013; 75: 102-5 
28. Wetzel J, Pilz S, Grübler MR et al. Plasma parathyroid hormone and cardiovascular disease in treatment-naive patients with primary hyperparathyroidism: The EPATH trial. J Clin Hypertens 2017;Aug 20. [Epub ahead of print]

29. Akhabue E, Thiboutot J, Cheng J-W et al. New and emerging risk factors for coronary heart disease. Am J Med Sci 2014; 347: 151-8.

30. Cannon CP. Cardiovascular disease and modifiable cardiometabolic risk factors. Clin Cornerstone 2007; 8: 11-28.

31. Andersson P, Rydberg E, Willenheimer R. Primary hyperparathyroidism and heart disease--a review. Eur Hear J 2004; 25: $1776-87$.

32. Walker $\mathrm{MD}$, Fleischer $\mathrm{J}$, Rundek $\mathrm{T}$ et al. Carotid vascular abnormalities in primary hyperparathyroidism. J Clin Endocrinol Metab 2009; 94: 3849-56.

33. Ljunghall S, Palmer M, Akerstrom G, Wide L. Diabetes mellitus, glucose tolerance and insulin response to glucose in patients with primary hyperparathyroidism before and after parathyroidectomy. Eur J Clin Invest 1983; 13: 373-7.

34. Almqvist EG, Bondeson AG, Bondeson L, Svensson J. Increased markers of inflammation and endothelial dysfunction in patients with mild primary hyperparathyroidism. Scand J Clin Lab Invest 2011; 71: 139-44.
35. Luigi $\mathrm{P}$, Chiara FM, Laura Z et al. Arterial hypertension, metabolic syndrome and subclinical cardiovascular organ damage in patients with asymptomatic primary hyperparathyroidism before and after parathyroidectomy: Preliminary results. Int J Endocrinol 2012; 2012: 408295

36. Rao DS, Honasoge M, Divine GW et al. Effect of vitamin D nutrition on parathyroid adenoma weight: Pathogenetic and clinical implications. J Clin Endocrinol Metab 2000; 85: 1054-8.

37. Moosgaard B, Vestergaard P, Heickendorff L, Melsen F, Christiansen P, Mosekilde L. Vitamin D status, seasonal variations, parathyroid adenoma weight and bone mineral density in primary hyperparathyroidism. Clin Endocrinol (Oxf) 2005; 63: 506-13.

Corresponding Author: Muhammed Kizilgul, Department of Endocrinology and Metabolism, Dışkapı Teaching and Research Hospital, Ankara, Turkey

E-mail: muhammedkzgl@gmail.com 